Providence College

DigitalCommons@Providence

$4-22-2020$

\title{
Development Of New Methodology Towards Accessing \\ 2-Imidazoline Scaffolds For Combatting Tuberculosis And \\ Multiple Myeloma By Proteasome Modulation
}

\author{
Karen Saldarriaga \\ Providence College \\ Victoria Rasmussen \\ Providence College
}

Follow this and additional works at: https://digitalcommons.providence.edu/chemistry_students

Part of the Biochemistry, Biophysics, and Structural Biology Commons

Saldarriaga, Karen and Rasmussen, Victoria, "Development Of New Methodology Towards Accessing 2-Imidazoline Scaffolds For Combatting Tuberculosis And Multiple Myeloma By Proteasome Modulation" (2020). Chemistry \& Biochemistry Student Scholarship. 9.

https://digitalcommons.providence.edu/chemistry_students/9

This Poster is brought to you for free and open access by the Chemistry \& Biochemistry at DigitalCommons@Providence. It has been accepted for inclusion in Chemistry \& Biochemistry Student Scholarship by an authorized administrator of DigitalCommons@Providence. For more information, please contact dps@providence.edu. 
